\title{
Hypometabolic Responses to Chronic Hypoxia: A Potential Role for Membrane Lipids
}

\author{
Elie Farhat and Jean-Michel Weber*iD \\ Biology Department, University of Ottawa, Ottawa, ON K1N 6N5, Canada; efarh086@uottawa.ca \\ * Correspondence: jmweber@uottawa.ca
}

\begin{abstract}
Metabolic suppression is an essential strategy to cope with chronic hypoxia. This review examines the physiological processes used to survive in low oxygen environments. It proposes a novel mechanism-the remodeling of membrane lipids-to suppress ATP use and production. Temperature (homeoviscous adaptation), diet (natural doping in migrant birds) and body mass (membrane pacemaker of metabolism) have an impact on the lipid composition of membranes, which, in turn, modulates metabolic capacity. Vertebrate champions of hypoxia tolerance show extensive changes in membrane lipids upon in vivo exposure to low oxygen. These changes and those observed in hibernating mammals can promote the downregulation of ion pumps (major ATP consumers), ion channels, mitochondrial respiration capacity (state 3, proton leak, cytochrome c oxidase), and energy metabolism ( $\beta$-oxidation and glycolysis). A common membrane signal regulating the joint inhibition of ion pumps and channels could be an exquisite way to preserve the balance between ATP supply and demand in hypometabolic states. Membrane remodeling together with more traditional mechanisms could work in concert to cause metabolic suppression.
\end{abstract}

Citation: Farhat, E.; Weber, J.-M. Hypometabolic Responses to Chronic Hypoxia: A Potential Role for Membrane Lipids. Metabolites 2021, 11, 503. https://doi.org/10.3390/ metabo11080503

\section{Academic Editors: Matthew}

Pamenter, Ken Storey and Michael Lalk

Received: 7 July 2021

Accepted: 29 July 2021

Published: 31 July 2021

Publisher's Note: MDPI stays neutral with regard to jurisdictional claims in published maps and institutional affiliations.

Copyright: (c) 2021 by the authors. Licensee MDPI, Basel, Switzerland. This article is an open access article distributed under the terms and conditions of the Creative Commons Attribution (CC BY) license (https:/ / creativecommons.org/licenses/by/ $4.0 /)$.
Keywords: metabolic suppression; hypometabolism; hypoxia tolerance; low oxygen stress; membrane remodeling; cholesterol; phospholipids; fatty acids; $\mathrm{Na}^{+} / \mathrm{K}^{+}$-ATPase; energy metabolism; mitochondrial respiration

\section{Introduction}

Hypoxia is a ubiquitous state of low oxygen common to many aquatic and terrestrial environments. It occurs in warm waters where $\mathrm{O}_{2}$ solubility is low, in ice-covered lakes and streams where exchange through the surface is restricted, at high altitude, and in deep underground burrows [1-3]. Global warming is exacerbating the problem, particularly in oceans, where oxygen minimum "dead" zones are expanding rapidly [4]. Except for a few unusually tolerant species, hypoxia is lethal to most animals as they eventually fail to match ATP supply with demand [5]. Champions of hypoxia tolerance like some cyprinid fish, freshwater turtles and African mole rats can easily withstand several weeks of low $\mathrm{O}_{2}$ by suppressing their metabolic rate [6,7]. This critical response can only be achieved through the parallel downregulation of ATP-consuming processes [5] and energy metabolism [8-10]. The simultaneous reduction in ATP supply and demand is realized via post-translational and post-transcriptional modifications involving phosphorylation/dephosphorylation reactions, association of enzymes with subcellular structures [11], activation of 5'-AMPactivated protein kinase (AMPK) [12], and epigenetic mechanisms [13]. It has been proposed that altering the composition of membrane lipids could also be used to promote hypometabolism $[14,15]$. The membrane changes discovered in these studies can contribute to metabolic suppression by reducing the activity of integral proteins. Extensive work on artificial or manipulated natural membranes has characterized a clear functional link between the lipid composition of membranes and the activity of embedded proteins [16-22]. Recent experiments have demonstrated that goldfish [14] and naked mole-rats (NMR) [15] exposed to chronic hypoxia alter membrane lipids in tissue-specific ways that can promote metabolic suppression. 
The goal of this review is to examine current information on the physiological mechanisms used by tolerant species to suppress metabolic rate in chronic hypoxia. Here, we define chronic hypoxia as exposure to low environmental $\mathrm{O}_{2}$ for a minimum of one week. Particular emphasis is placed on how chronic hypoxia alters: (i) membrane responses and how changes in their lipid constituents could modulate ion pumps (ATP use) and channels, (ii) key enzymes of energy metabolism (ATP supply), and (iii) mitochondrial respiration. The functional contributions of these 3 levels of regulation to the orchestration of metabolic suppression are addressed. The roles of AMPK and epigenetics are not further discussed here because they have been extensively reviewed elsewhere [12,13].

\section{Membrane Lipids: Response to Environmental Stress and How They Affect Metabolism, Ion Pumps and Channels}

To remain functional in variable environments, membranes modify their chemical structure in multiple ways. This section deals with the effects of chronic hypoxia on the lipid composition of membranes. It starts by examining previous work on the well characterized effects of temperature, toxins, diet, and phylogeny to illustrate how hypoxiadriven membrane remodeling can be used to suppress metabolism.

\subsection{Temperature and Toxins}

Membrane fluidity varies with temperature [23], but most animals manage to keep it constant by altering their lipid constituents-phospholipids and cholesterol-through a mechanism known as homeoviscous adaptation [24,25]. This response is most common in ectotherms [24,26,27], but has also been reported in isolated mammalian cells [26]. Animals counteract the effects of increasing temperature on membrane fluidity by decreasing the degree of unsaturation and/or increasing the fatty acid chain length of phospholipids [23]. Because cholesterol affects the interactions between phospholipids, changes in its abundance are also used to stabilize membrane fluidity and cope with a variety of environmental stresses. Cholesterol promotes an "intermediate state" in phospholipids that causes an increase in fluidity below and a decrease in fluidity above the liquid-gel phase transition temperature [27]. It also interacts with the polar head groups of phospholipids to decrease membrane permeability $[28,29]$. Interestingly, homeoviscous adaptation can even occur in response to environmental pollutants. For example, goldfish chronically exposed to the membrane fluidizer PCB-153 can use changes in cholesterol abundance to counteract the effects of the toxin and maintain constant fluidity [30].

\subsection{Diet}

Membranes are affected by the lipid composition of the diet in various animal groups including fish [31], birds [32,33] and mammals [34]. Some species use this mechanism strategically to prepare for hibernation [35] or long-distance migration [36]. The likelihood of golden-mantled ground squirrels to enter and survive hibernation is greatly increased when they switch from a high polyunsaturated fatty acid (PUFA) diet in the summer to a low PUFA diet in the fall before entering torpor [37]. Shorthand naming of individual fatty acids uses the $\mathbf{n}-\mathbf{x} \mathbf{y}: \mathbf{z}$ nomenclature where $\mathbf{x}$ indicates the position of the first double bond from the methyl carbon end (n), $\mathbf{y}$ is the total number of carbons in the acyl chain, and $\mathbf{z}$ is the number of double bonds. Specific fatty acids such as the n-6 PUFA linoleic acid (n-6 18:2) have been shown to enhance hibernation capacity [35,38]. Similarly, some birds drastically improve their ability for aerobic metabolism by feeding on diets high in longchain n-3 PUFAs. Semipalmated sandpipers double their body mass just before migrating across the Atlantic Ocean between Canada and Brazil by eating large amounts of n-3 PUFA: from mud shrimps loaded with eicosapentaenoic acid (n-3 20:5) and docosahexaenoic acid (n-3 22:6). This "natural doping" strategy greatly improves the aerobic capacity of the long-distance migrant $[39,40]$, and has been further demonstrated experimentally in sedentary quails [32]. Therefore, animals can manipulate the lipid composition of their membranes by selecting particular diets to alter basal metabolism or aerobic capacity for successful hibernation or long-distance migration. 


\subsection{Membrane Pacemaker Theory of Metabolism}

The membrane pacemaker theory of metabolism stipulates that the fatty acid composition of membrane phospholipids sets the basal metabolic rate of organisms [41]. Its original formulation was based on the combined observations that: (i) the mass-specific metabolic rate of animals decreases with body size, (ii) the average number of double bonds in membrane fatty acids also decreases with size, and (iii) integral proteins are activated when membrane unsaturation increases [41]. This theory was inferred from the correlation between the lipid composition of membranes and body size discovered in mammals [23], and was subsequently supported by many other studies [21,42]. The validity of the pacemaker theory has been questioned, however, because the relationship between body size and membrane composition first characterized in mammals disappears when the effects of phylogeny are taken into account [43]. More recently, analyses using orchid bees [44] and cypriniform fish [45] provide support for the theory, even after correction for phylogeny. If the metabolic rate of organisms is set by membrane composition on an evolutionary time scale, the same mechanism could be used to suppress metabolism in hypoxia within an animal's lifespan.

\subsection{Potential Role for Membrane Regulation of ATP Use and Production in Chronic Hypoxia}

The main pitfall faced by organisms exposed to prolonged hypoxia is their ultimate failure to match ATP supply with demand [5]. Thus, it is imperative to downregulate ATP-consuming and ATP-supplying processes to survive in low $\mathrm{O}_{2}$ environments. This can be achieved by modulating enzymes that play essential roles in regulating ATP use (ATPases) and ATP production (energy metabolism). This section deals with membrane regulation of $\mathrm{Na}^{+} / \mathrm{K}^{+}$-ATPase and key enzymes of energy metabolism during chronic hypoxia. The downregulation of these enzymes via other mechanisms such as epigenetics, post-translational and post-transcriptional modifications as well as AMPK are beyond the scope of this review and are reviewed elsewhere [12,13].

\subsubsection{Membrane Regulation of $\mathrm{Na}^{+} / \mathrm{K}^{+}$-ATPase (ATP Use)}

$\mathrm{Na}^{+} / \mathrm{K}^{+}$-ATPase is an integral protein that is responsible for approximately $25 \%$ of total ATP consumption [46]. This enzyme requires constant ATP supply to maintain transmembrane $\mathrm{Na}^{+}$and $\mathrm{K}^{+}$gradients. When ATP production is reduced under $\mathrm{O}_{2}$-limiting conditions, $\mathrm{Na}^{+} / \mathrm{K}^{+}$-ATPase becomes the dominant energy sink of the cell [47]. This pump is particularly important in the brain where it drives action potentials by regulating $\mathrm{Na}^{+}$ and $\mathrm{K}^{+}$currents. Any failure of its normal function eventually causes a spike in intracellular calcium that can lead to neuronal death [5]. Surprisingly, only a handful of studies have examined the effects of chronic hypoxia on $\mathrm{Na}^{+} / \mathrm{K}^{+}$-ATPase (see Table 1) because the bulk of previous research has focused on acute hypoxia and anoxia. The hypoxia tolerant species measured to date, as well as the rat, downregulate $\mathrm{Na}^{+} / \mathrm{K}^{+}$-ATPase when exposed to chronic hypoxia. Unfortunately, this limited information does not allow one to determine if tolerant and sensitive species show different $\mathrm{Na}^{+} / \mathrm{K}^{+}$-ATPase responses. Previous studies have mostly examined $\mathrm{Na}^{+} / \mathrm{K}^{+}$-ATPase in the vertebrate brain, and it will be important to characterize the effects of chronic hypoxia on other tissues from both, hypoxia-sensitive and -tolerant animals. The general downregulation of $\mathrm{Na}^{+} / \mathrm{K}^{+}$-ATPase observed to date (see Table 1) suggests that ion channels are also inhibited by prolonged hypoxia to prevent a harmful increase in intracellular calcium. 
Table 1. Effects of chronic hypoxia (minimum 1 week) on the maximal activity of $\mathrm{Na}+/ \mathrm{K}+$-ATPase in various animals.

\begin{tabular}{|c|c|c|c|c|}
\hline Species & Tissue & $\begin{array}{c}\mathrm{Na}^{+} / \mathrm{K}^{+} \text {-ATPase } \\
\text { Response }\end{array}$ & $\begin{array}{l}\text { Hypoxia } \\
\text { Duration } \\
\text { (Weeks) }\end{array}$ & Reference \\
\hline $\begin{array}{c}\text { Mouse } \\
(M u s \text { musculus })\end{array}$ & Brain & - & 3 & {$[48]$} \\
\hline $\begin{array}{c}\text { Rat } \\
\text { (Rattus norvegicus) }\end{array}$ & Brain & $\sim 30-40 \% \downarrow$ & 4 & [49] \\
\hline \multirow{2}{*}{$\begin{array}{l}\text { Naked mole rat } \\
\text { (Heterocephalus glaber) }\end{array}$} & Brain & $77 \% \downarrow$ & 4 & [15] \\
\hline & $\begin{array}{c}\text { Liver } \\
\text { Temporalis, heart }\end{array}$ & $\begin{array}{l}41 \% \uparrow \\
-\end{array}$ & & $\begin{array}{l}{[15]} \\
{[15]}\end{array}$ \\
\hline $\begin{array}{c}\text { Crucian carp } \\
\text { (Carassius carassius) }\end{array}$ & Heart & $33 \% \downarrow$ & 3 & [50] \\
\hline \multirow[t]{2}{*}{$\begin{array}{c}\text { Goldfish } \\
\text { (Carassius auratus) }\end{array}$} & Brain & $40 \% \downarrow$ & 4 & {$[51]$} \\
\hline & Liver, white muscle & - & & [51] \\
\hline
\end{tabular}

Current evidence shows that the activity of $\mathrm{Na}^{+} / \mathrm{K}^{+}$-ATPase is affected by the local lipid environment, in particular by the relative abundance of specific fatty acids and cholesterol. Multi-species comparisons within birds or mammals show that $\mathrm{Na}^{+} / \mathrm{K}^{+}-$ ATPase activity is positively correlated with membrane n-3 22:6 abundance [52], and a clear functional link between these parameters has been demonstrated with cross-species experiments. $\mathrm{Na}^{+} / \mathrm{K}^{+}$-ATPase taken from an ectotherm is activated when reconstituted in a mammalian membrane that is richer in $n-322: 6$, and the reverse experiment has confirmed that $22: 6$ is an activator of this essential pump [53,54]. Finally, changing intrinsic cholesterol abundance downregulates $\mathrm{Na}^{+} / \mathrm{K}^{+}$-ATPase in humans, rabbits, guinea pigs and rats $[16-18,55]$.

2.4.2. Membrane Regulation of Glycolysis, $\beta$-Oxidation and the Tricarboxylic Acid (TCA) Cycle (ATP Production)

The overall effects of chronic hypoxia on all glycolytic enzymes are variable, but some trends can be observed in endotherms (Tables 2-4). No pattern can be found for the glycolytic response of ectotherms, and it is presently unclear whether a general response to chronic hypoxia exists for this group of animals. Endotherms generally upregulate hexokinase (HK; Table 2), maintain phosphofructokinase (PFK; Table 3), and downregulate pyruvate kinase (PK; Table 4). The opposite responses shown by HK (activation) and PK (inhibition) also support the notion that hypoxic endotherms simply maintain normal glycolytic supply of ATP. As the last enzyme of the glycolytic pathway, lactate dehydrogenase (LDH) activity is often used as an indicator of tissue capacity for anaerobic ATP production. The lack of a clear activation or downregulation of LDH by chronic hypoxia in ecto- and endotherms (Table 5) indicates that animals do not generally rely on anaerobic metabolism to survive in hypoxic environments. Glycolytic supply of pyruvate to the TCA cycle seems to be regulated differently among species, irrespective of their tolerance to hypoxia, and this regulation favors metabolic suppression in some cases. 
Table 2. Effects of chronic hypoxia (minimum 1 week) on the maximal activity of hexokinase (HK) in various animals.

\begin{tabular}{|c|c|c|c|c|}
\hline Species & Tissue & HK Response & $\begin{array}{c}\text { Hypoxia } \\
\text { Duration } \\
\text { (Weeks) }\end{array}$ & Reference \\
\hline \multirow[t]{2}{*}{$\begin{array}{c}\text { Deer mouse } \\
\text { (Peromyscus maniculatus) }\end{array}$} & Gastrocnemius & $35 \% \uparrow$ & $6-8$ & [56] \\
\hline & Gastrocnemius & - & & [56] \\
\hline $\begin{array}{c}\text { Mouse } \\
(M u s \text { musculus })\end{array}$ & Brain & - & 3 & {$[48]$} \\
\hline $\begin{array}{c}\text { Rat } \\
\text { (Rattus norvegicus) }\end{array}$ & $\begin{array}{c}\text { Gastrocnemius, soleus, heart, } \\
\text { brain }\end{array}$ & $8-105 \% \uparrow$ & $3-10$ & [57-60] \\
\hline $\begin{array}{l}\text { Gulf killifish } \\
\text { (Fundulus grandis) }\end{array}$ & Heart, brain & $16-28 \% \uparrow$ & 4 & {$[9]$} \\
\hline \multirow{4}{*}{$\begin{array}{c}\text { Goldfish } \\
\text { (Carassius auratus) }\end{array}$} & Liver & - & & [9] \\
\hline & Brain & $12 \% \downarrow$ & 4 & [51] \\
\hline & White muscle & $82 \% \uparrow$ & & \\
\hline & $\begin{array}{l}\text { White muscle, red muscle, } \\
\text { liver }\end{array}$ & - & $4-6$ & {$[51,61]$} \\
\hline $\begin{array}{c}\text { Tench } \\
\text { (Tinca tinca) }\end{array}$ & White muscle & $67 \% \downarrow$ & 6 & [62] \\
\hline $\begin{array}{c}\text { Chinese shrimp } \\
\text { (Fenneropenaeus chinensis) }\end{array}$ & $\begin{array}{l}\text { Red muscle, liver } \\
\text { pancreas, pleopod, } \\
\text { abdominal muscle }\end{array}$ & $24-26 \% \downarrow$ & 2 & {$[63]$} \\
\hline
\end{tabular}

Table 3. Effects of chronic hypoxia (minimum 1 week) on the maximal activity of phosphofructokinase (PFK) in various animals.

\begin{tabular}{|c|c|c|c|c|}
\hline Species & Tissue & PFK Response & $\begin{array}{l}\text { Hypoxia } \\
\text { Duration } \\
\text { (Weeks) }\end{array}$ & Reference \\
\hline $\begin{array}{c}\text { Deer mouse } \\
\text { (Peromyscus maniculatus) }\end{array}$ & Gastrocnemius & - & $6-8$ & [56] \\
\hline $\begin{array}{c}\text { Rat } \\
\text { (Rattus norvegicus) }\end{array}$ & $\begin{array}{l}\text { Heart, soleus, gastrocnemius, } \\
\text { caudal nerve }\end{array}$ & - & $3-10$ & [57-59] \\
\hline $\begin{array}{l}\text { Gulf killifish } \\
\text { (Fundulus grandis) }\end{array}$ & White muscle & $25 \% \downarrow$ & 4 & [9] \\
\hline & $\begin{array}{l}\text { Liver } \\
\text { Heart, brain }\end{array}$ & $\begin{array}{c}63 \% \uparrow \\
-\end{array}$ & & $\begin{array}{l}{[9]} \\
{[9]}\end{array}$ \\
\hline $\begin{array}{c}\text { Nile tilapia } \\
\text { (Oreochromis niloticus) }\end{array}$ & Liver, white muscle & $59-123 \uparrow$ & 4 & [64] \\
\hline $\begin{array}{c}\text { Tench } \\
\text { (Tinca tinca) }\end{array}$ & White muscle & - & 6 & [62] \\
\hline $\begin{array}{c}\text { Chinese shrimp } \\
\text { (Fenneropenaeus chinensis) }\end{array}$ & $\begin{array}{l}\text { Red muscle, liver } \\
\text { hepatopancreas, pleopod, } \\
\text { abdominal muscle }\end{array}$ & $\begin{array}{l}98-120 \% \uparrow \\
16-31 \% \downarrow\end{array}$ & 2 & {$[62]$} \\
\hline
\end{tabular}


Table 4. Effects of chronic hypoxia (minimum 1 week) on the maximal activity of pyruvate kinase (PK) in various animals.

\begin{tabular}{|c|c|c|c|c|}
\hline Species & Tissue & PK Response & $\begin{array}{l}\text { Hypoxia } \\
\text { Duration } \\
\text { (Weeks) }\end{array}$ & Reference \\
\hline $\begin{array}{c}\text { Deer mouse } \\
\text { (Peromyscus maniculatus) }\end{array}$ & Gastrocnemius & - & $6-8$ & {$[56]$} \\
\hline \multirow[t]{2}{*}{$\begin{array}{c}\text { Rat } \\
\text { (Rattus norvegicus) }\end{array}$} & Heart, soleus & - & 3 & {$[58]$} \\
\hline & Gastrocnemius & - & 4 & [57] \\
\hline $\begin{array}{c}\text { Naked mole-rat } \\
\text { (Heterocephalus glaber) }\end{array}$ & $\begin{array}{l}\text { Liver, temporalis muscle, brain, } \\
\text { heart, kidney }\end{array}$ & $61-99 \% \downarrow$ & 4 & [15] \\
\hline $\begin{array}{c}\text { Mouse } \\
(\text { Mus musculus })\end{array}$ & Liver & $65 \% \downarrow$ & 4 & {$[65]$} \\
\hline $\begin{array}{l}\text { Northern shrimp } \\
\text { (Pandalus borealis) }\end{array}$ & White muscle & - & 1 & {$[66]$} \\
\hline $\begin{array}{l}\text { Greenland halibut } \\
\text { (Reinhardtius hippoglossoides) }\end{array}$ & White muscle & $46 \% \downarrow$ & & {$[66]$} \\
\hline $\begin{array}{l}\text { Common carp } \\
\text { (Cyprinus carpio) }\end{array}$ & White muscle & - & 1 & [67] \\
\hline \multirow[t]{2}{*}{$\begin{array}{c}\text { Nile tilapia } \\
\text { (Oreochromis niloticus) }\end{array}$} & Liver & $61-96 \% \uparrow$ & 4 & {$[64]$} \\
\hline & White muscle & - & & [64] \\
\hline $\begin{array}{l}\text { Gulf killifish } \\
\text { (Fundulus grandis) }\end{array}$ & White muscle & $23 \% \downarrow$ & 4 & [9] \\
\hline \multirow{3}{*}{$\begin{array}{c}\text { Goldfish } \\
\text { (Carassius auratus) }\end{array}$} & $\begin{array}{c}\text { Heart } \\
\text { Liver, brain }\end{array}$ & $\begin{array}{c}24 \% \uparrow \\
-\end{array}$ & & $\begin{array}{l}{[9]} \\
{[9]}\end{array}$ \\
\hline & White and red muscle, liver & - & 6 & {$[61]$} \\
\hline & $\begin{array}{c}\text { Liver } \\
\text { White muscle, brain }\end{array}$ & $\begin{array}{l}47 \% \downarrow \\
-\end{array}$ & 4 & $\begin{array}{l}{[51]} \\
{[51]}\end{array}$ \\
\hline $\begin{array}{c}\text { Tench } \\
\text { (Tinca tinca) }\end{array}$ & White and red muscle & - & 6 & {$[62]$} \\
\hline $\begin{array}{c}\text { Chinese shrimp } \\
\text { (Fenneropenaeus chinensis) }\end{array}$ & $\begin{array}{c}\text { Liver } \\
\text { hepatopancreas, pleopod, } \\
\text { abdominal muscle }\end{array}$ & $\begin{array}{c}86 \% \uparrow \\
14-39 \% \downarrow\end{array}$ & 2 & $\begin{array}{l}{[62]} \\
{[63]}\end{array}$ \\
\hline
\end{tabular}

Table 5. Effects of chronic hypoxia (minimum 1 week) on the maximal activity of lactate dehydrogenase (LDH) in various animals.

\begin{tabular}{|c|c|c|c|c|}
\hline Species & Tissue & LDH Response & $\begin{array}{l}\text { Hypoxia } \\
\text { Duration } \\
\text { (Weeks) }\end{array}$ & Reference \\
\hline $\begin{array}{c}\text { Deer mouse } \\
\text { (Peromyscus maniculatus) }\end{array}$ & Gastrocnemius, diaphragm & - & $6-8$ & {$[68,69]$} \\
\hline \multirow[t]{2}{*}{$\begin{array}{c}\text { Mouse } \\
(\text { Mus musculus })\end{array}$} & Hindlimb muscles & $28 \% \downarrow$ & 1 & [70] \\
\hline & Brain, liver & - & $3-4$ & {$[48,65]$} \\
\hline \multirow[t]{2}{*}{$\begin{array}{c}\text { Rat } \\
\text { (Rattus norvegicus) }\end{array}$} & Soleus & - & 3 & {$[58]$} \\
\hline & $\begin{array}{c}\text { Gastrocnemius, } \\
\text { heart, gastrocnemius and liver } \\
\text { mitochondria }\end{array}$ & $25-54 \% \uparrow$ & $1-3$ & {$[65,66,71]$} \\
\hline \multirow[t]{2}{*}{$\begin{array}{c}\text { Naked mole-rat } \\
\text { (Heterocephalus glaber) }\end{array}$} & Brain, liver, temporalis & $62-82 \% \downarrow$ & 4 & [15] \\
\hline & Kidney & $81 \% \uparrow$ & & {$[15]$} \\
\hline
\end{tabular}


Table 5. Cont.

\begin{tabular}{|c|c|c|c|c|}
\hline Species & Tissue & LDH Response & $\begin{array}{l}\text { Hypoxia } \\
\text { Duration } \\
\text { (Weeks) }\end{array}$ & Reference \\
\hline $\begin{array}{l}\text { Northern Shrimp } \\
\text { (Pandalus borealis) }\end{array}$ & White muscle & $45-88 \% \downarrow$ & 1 & {$[66]$} \\
\hline $\begin{array}{l}\text { Greenland halibut } \\
\text { (Reinhardtius hippoglossoides) }\end{array}$ & White muscle & $58 \% \downarrow$ & & {$[66]$} \\
\hline $\begin{array}{l}\text { Common carp } \\
\text { (Cyprinus carpio) }\end{array}$ & White muscle & - & 1 & [67] \\
\hline & Liver & $\sim 60 \% \uparrow$ & & [67] \\
\hline $\begin{array}{c}\text { Nile tilapia } \\
\text { (Oreochromis niloticus) }\end{array}$ & Liver, white muscle & $80-176 \% \uparrow$ & 4 & {$[64]$} \\
\hline $\begin{array}{l}\text { Gulf killifish } \\
\text { (Fundulus grandis) }\end{array}$ & White muscle & $30 \% \downarrow$ & 4 & {$[9]$} \\
\hline & $\begin{array}{c}\text { Liver } \\
\text { Heart, brain }\end{array}$ & $\begin{array}{c}30 \% \uparrow \\
-\end{array}$ & & $\begin{array}{l}{[9]} \\
{[9]}\end{array}$ \\
\hline $\begin{array}{c}\text { Goldfish } \\
\text { (Carassius auratus) }\end{array}$ & White muscle, red muscle, liver, brain & - & $4-6$ & {$[51,61]$} \\
\hline $\begin{array}{c}\text { Tench } \\
\text { (Tinca tinca) }\end{array}$ & White and red muscles & - & 6 & [62] \\
\hline $\begin{array}{c}\text { Chinese shrimp } \\
\text { (Fenneropenaeus chinensis) }\end{array}$ & $\begin{array}{l}\text { Liver } \\
\text { hepatopancreas, pleopod, } \\
\text { abdominal muscle }\end{array}$ & $\begin{array}{c}116 \% \uparrow \\
26-33 \% \downarrow\end{array}$ & 2 & [63] \\
\hline
\end{tabular}

$\beta$-oxidation is a mitochondrial pathway that breaks down fatty acids to acetyl-CoA and fuels the TCA cycle. The transmembrane enzyme carnitine palmitoyl transferase (CPT) exerts the strongest control on $\beta$-oxidation flux [72], and it is modulated by changes in membrane composition. Chronic hypoxia causes a general decrease in CPT (Table 6) and 3-hydroxyacyl-CoA dehydrogenase (HOAD) activity (another enzyme that regulates $\beta$-oxidation; Table 7). The only two exceptions to this pattern are CPT activation in tench liver and red muscle [62], and HOAD activation in goldfish brain [51]. Otherwise, general downregulation of $\beta$-oxidation appears to be a common way to adjust ATP supply to the lower energy demand afforded by hypometabolism.

Table 6. Effects of chronic hypoxia (minimum 1 week) on the maximal activity of carnitine palmitoyl transferase (CPT) in various animals.

\begin{tabular}{|c|c|c|c|c|}
\hline Species & Tissue & CPT Response & $\begin{array}{c}\text { Hypoxia } \\
\text { Duration } \\
\text { (Weeks) }\end{array}$ & Reference \\
\hline \multirow[t]{2}{*}{$\begin{array}{c}\text { Rat } \\
\text { (Rattus norvegicus) }\end{array}$} & Muscle, heart & $16-34 \% \downarrow$ & 5 & {$[73,74]$} \\
\hline & Liver, gastrocnemius mitochondria & - & $1-5$ & {$[74,75]$} \\
\hline \multirow{2}{*}{$\begin{array}{c}\text { Naked mole-rat } \\
\text { (Heterocephalus glaber) }\end{array}$} & Liver, temporalis muscle & $89-98 \% \downarrow$ & 4 & {$[15]$} \\
\hline & Brain, heart, kidney & - & & {$[15]$} \\
\hline \multirow[t]{2}{*}{$\begin{array}{c}\text { Mouse } \\
\text { (Mus musculus) }\end{array}$} & Skeletal muscle & $65 \% \downarrow$ & 1 & {$[76]$} \\
\hline & Heart & - & & {$[76]$} \\
\hline \multirow[t]{2}{*}{$\begin{array}{c}\text { Goldfish } \\
\text { (Carassius auratus) }\end{array}$} & Brain & $18 \% \downarrow$ & 4 & {$[51]$} \\
\hline & Liver, white muscle & - & & [51] \\
\hline \multirow{2}{*}{$\begin{array}{c}\text { Tench } \\
\text { (Tinca tinca) }\end{array}$} & Red muscle, liver & $162-236 \% \uparrow$ & 6 & {$[62]$} \\
\hline & White muscle & - & & {$[62]$} \\
\hline
\end{tabular}


Table 7. Effects of chronic hypoxia (minimum 1 week) on the maximal activity of 3-hydroxyacyl-CoA dehydrogenase (HOAD) in various animals.

\begin{tabular}{|c|c|c|c|c|}
\hline Species & Tissue & HOAD Response & $\begin{array}{c}\text { Hypoxia } \\
\text { Duration } \\
\text { (Weeks) }\end{array}$ & Reference \\
\hline $\begin{array}{c}\text { Deer mouse } \\
\text { (Peromyscus maniculatus) }\end{array}$ & Gastrocnemius, liver & - & $6-8$ & [56] \\
\hline $\begin{array}{c}\text { Mouse } \\
(\text { Mus musculus })\end{array}$ & Left ventricle & $36 \% \downarrow$ & 4 & {$[77]$} \\
\hline $\begin{array}{c}\text { Rat } \\
\text { (Rattus norvegicus) }\end{array}$ & $\begin{array}{c}\text { Heart, skeletal, liver and liver } \\
\text { mitochondria }\end{array}$ & $20-71 \% \downarrow$ & $1-5$ & {$[58,73-75]$} \\
\hline \multirow{3}{*}{$\begin{array}{c}\text { Naked mole-rat } \\
\text { (Heterocephalus glaber) }\end{array}$} & Soleus, gastrocnemius mitochondria & - & $1-3$ & {$[58,75]$} \\
\hline & Liver, temporalis muscle & $69-93 \% \downarrow$ & 4 & {$[15]$} \\
\hline & Brain, heart, kidney & - & & [15] \\
\hline $\begin{array}{c}\text { Mouse } \\
\text { (Mus musculus) }\end{array}$ & Heart, skeletal & - & 1 & [76] \\
\hline \multirow[t]{2}{*}{$\begin{array}{c}\text { Goldfish } \\
\text { (Carassius auratus) }\end{array}$} & Brain & $70 \% \uparrow$ & 4 & [51] \\
\hline & Liver, White muscle & - & & [51] \\
\hline
\end{tabular}

The TCA cycle generates NADH and $\mathrm{FADH}_{2}$, which feed into mitochondria to yield high amounts of ATP. Reliance on this pathway becomes difficult when $\mathrm{O}_{2}$ availability is reduced. Most animals respond to chronic hypoxia by downregulating citrate synthase (CS) in various tissues (Table 8). The only two studies showing CS activation are for the heart in sablefish [78] and NMR [15]. Overall, however, flux capacity through the TCA cycle is lowered in animals exposed to chronic hypoxia. The general decrease in CS activity also indicates that mitochondrial density is reduced across tissues [71].

Table 8. Effects of chronic hypoxia (minimum 1 week) on the maximal activity of citrate synthase (CS) in various animals.

\begin{tabular}{|c|c|c|c|c|}
\hline Species & Tissue & CS Response & $\begin{array}{l}\text { Hypoxia } \\
\text { Duration } \\
\text { (Weeks) }\end{array}$ & Reference \\
\hline $\begin{array}{c}\text { Deer mouse } \\
\text { (Peromyscus maniculatus) }\end{array}$ & Liver, gastrocnemius, diaphragm & - & $6-8$ & {$[64,76,77]$} \\
\hline \multirow[t]{2}{*}{$\begin{array}{c}\text { Mouse } \\
\text { (Mus musculus })\end{array}$} & Liver mitochondria & $34 \% \downarrow$ & 1 & [75] \\
\hline & $\begin{array}{l}\text { Hindlimb muscles, heart } \\
\text { Gastrocnemius mitochondria } \\
\text { Brain, liver }\end{array}$ & $\begin{array}{l}- \\
-\end{array}$ & $\begin{array}{c}1-4 \\
1 \\
3-4\end{array}$ & $\begin{array}{c}{[70,77]} \\
{[75]} \\
{[48,65]}\end{array}$ \\
\hline \multirow[t]{2}{*}{$\begin{array}{c}\text { Rat } \\
\text { (Rattus norvegicus) }\end{array}$} & Gastrocnemius & $34-39 \% \downarrow$ & 4 & [57] \\
\hline & Gastrocnemius, heart, liver & - & $3-5$ & {$[66,79,80]$} \\
\hline \multirow[t]{2}{*}{$\begin{array}{c}\text { Naked mole-rat } \\
\text { (Heterocephalus glaber) }\end{array}$} & Brain, liver, temporalis, kidney & $25-78 \% \downarrow$ & 4 & {$[15]$} \\
\hline & Heart & $94-115 \% \uparrow$ & & [15] \\
\hline $\begin{array}{c}\text { Goldfish } \\
\text { (Carassius auratus) }\end{array}$ & Brain, liver, white muscle & - & 4 & {$[51]$} \\
\hline \multirow[t]{2}{*}{$\begin{array}{l}\text { Common carp } \\
\text { (Cyprinus carpio) }\end{array}$} & White muscle & $\sim 25 \% \downarrow$ & 1 & {$[67]$} \\
\hline & Liver & - & & [67] \\
\hline $\begin{array}{l}\text { Northern shrimp } \\
\text { (Pandalus borealis) }\end{array}$ & White muscle & $40 \% \downarrow$ & 1 & {$[66]$} \\
\hline
\end{tabular}


Table 8. Cont.

\begin{tabular}{|c|c|c|c|c|}
\hline Species & Tissue & CS Response & $\begin{array}{c}\text { Hypoxia } \\
\text { Duration } \\
\text { (Weeks) }\end{array}$ & Reference \\
\hline $\begin{array}{c}\text { Greenland halibut } \\
\text { (Reinhardtius hippoglossoides) }\end{array}$ & White muscle & $33 \% \downarrow$ & & [66] \\
\hline $\begin{array}{c}\text { Chinese shrimp } \\
\text { (Fenneropenaeus chinensis) }\end{array}$ & pancreas, pleopod, abdominal muscle & $31-70 \% \downarrow$ & 2 & [63] \\
\hline $\begin{array}{c}\text { Sablefish } \\
\text { (Anoplopoma fimbria) }\end{array}$ & Heart & $20 \% \uparrow$ & 3 & [78] \\
\hline
\end{tabular}

Specific membrane fatty acids influence the activities of enzymes involved in energy metabolism. Briefly, fast glycolytic muscles contain more palmitic acid (16:0) and n-6 18:2, but less long-chain PUFA [79] than slow oxidative muscles, suggesting that glycolytic enzymes are downregulated by long-chain PUFA. Moreover, n-3 PUFA levels are positively correlated with the activities of $\beta$-oxidation and TCA cycle enzymes [80]. This is clearly evident in sedentary quails [32] and migrant sandpipers [40] that activate CS, HOAD and $\mathrm{CPT}$ after incorporating dietary long-chain n-3 PUFA in their membranes. The activity of CPT also increases in the presence of more n-3 20:5 in the membranes of adipocytes [81]. No information is currently available on whether modulating membrane cholesterol has similar repercussions on energy metabolism pathways as it does on ATPases. Overall, however, there is strong evidence that altering membrane phospholipids and cholesterol affects ATP supply and demand by activating or inhibiting key enzymes.

\subsection{Evidence for Membrane Regulation of Ion Channels}

Reducing ion pump activity in hypoxia is only possible with a matching decrease in ion leak so that vital transmembrane ion gradients are preserved. Therefore, it is essential to examine whether ion channels can also be downregulated by changing the lipid composition of membranes. Ion channels are integral membrane proteins surrounded by lipids and they contain a transmembrane domain that moves within the bilayer [82]. Membrane lipids are known to modulate ion channels directly or indirectly via specific lipid-protein interactions. This section reviews known mechanisms whereby changes in membrane PUFAs and cholesterol alter the function of $\mathrm{Ca}^{2+}, \mathrm{K}^{+}$and $\mathrm{Na}^{+}$channels as well as nicotinicoid receptors $[82,83]$. Depleting cholesterol experimentally causes an increase in $\mathrm{Ca}^{2+}$ uptake through the $\mathrm{Ca}^{2+}$ channel and the $\mathrm{Na}^{+} / \mathrm{Ca}^{2+}$ exchanger of the sarcolemma, whereas cholesterol enrichment decreases conductance of the $\mathrm{Ca}^{2+}$-dependent $\mathrm{K}^{+}$channel $[19,82]$. Negatively charged long chain fatty acids upregulate $\mathrm{Ca}^{2+}$-activated $\mathrm{K}^{+}$ channels with the strongest effect observed for cis unsaturated fatty acids [83]. Modifying membrane cholesterol from normal levels reduces the activity of $\mathrm{K}^{+}$channels [83,84]. Moreover, voltage-gated $\mathrm{Na}^{+}$channels are inhibited by PUFAs $[85,86]$ and cholesterol [84]. This occurs by shifting the steady-state inactivation kinetics of this voltage-gated ion channel in the direction of hyperpolarization, possibly via selective binding to the inactive site of the channel [86].

Membrane lipids also impact the function of ligand-gated ion channels such as nicotinicoid receptors. They include the excitatory acetylcholine and serotonin receptors as well as the inhibitory gamma-aminobutyric acid (GABA) receptors that are required to propagate neuronal signals. Functional acetylcholine receptors depend on the presence of both cholesterol and negatively charged phospholipids to support ion flux. On its own, cholesterol also alters the function of GABA, serotonin and acetylcholine receptors because this sterol is necessary for maintaining their optimal activity [82,83]. It has also been suggested that a decrease in hippocampal cholesterol levels could reduce $\mathrm{N}$-methylD-aspartate receptor (NMDA) signaling [87]. Overall, current information clearly shows that membrane lipids do not only modulate ion pumps, but also ion channels. 


\subsection{Potential Role of Membranes in the Regulation of Mitochondrial Function}

Mitochondria are major $\mathrm{O}_{2}$ consumers that produce ATP through oxidative phosphorylation: a process that couples the electron transport chain $(\mathrm{ETC}=$ enzyme complexes I to IV) with ATP synthase (complex V). The ETC pumps protons across the inner mitochondrial membrane to establish an electrochemical gradient that is used to phosphorylate ADP [88]. Oxygen is consumed at complex IV (cytochrome c oxidase, COX): the final electron acceptor that reduces $\mathrm{O}_{2}$ to water and contributes to generating the proton gradient [89]. All these protein complexes are transmembrane enzymes whose activities are modulated by changes in the phospholipid composition of the bilayer. Mitochondria also produce significant amounts of reactive oxygen species (ROS), particularly at complexes I and III [90]. These organelles are strategically placed to sense any changes in $\mathrm{O}_{2}$ and initiate organism-specific responses to hypoxia. Oxygen sensing can be done through a ROS-induced response that may cause rapid accumulation of $\mathrm{Ca}^{2+}$ and/or activation of hypoxia inducible factor (HIF) [88]. ROS can cause the formation of disulfide bonds, which may change the structure and function of proteins such as phosphatases, transcription factors and those involved in epigenetic modifications [12]. Severe hypoxia causes the depolarization of mitochondria that leads complex $\mathrm{V}$ to switch from ATP production to ATP consumption [91]. This exacerbates the existing ATP shortfall already induced by hypoxia and can eventually result in tissue failure. This section deals with the effects of chronic hypoxia and membrane lipids on the functional capacity of mitochondria by examining specific responses for the different respiration states and ETC complexes.

The effects of chronic hypoxia on the mitochondria of endotherms have only been investigated in rats and deer mice. After acclimation to hypoxia, rats decrease respiration capacity through ETC complexes I, II and IV in the heart [92] as well as state 3 (OXPHOS in the presence of substrates and ADP) and 4 (LEAK after ADP depletion) in the brain [93]. However, this response is not always consistent because another study shows no change in rat liver and heart [94]. Hypoxia-tolerant species like deer mice have different mitochondrial responses to low $\mathrm{O}_{2}$ to rats. They increase mitochondrial respiration (complexes I, II and IV) in the diaphragm [95], but maintain it in the gastrocnemius. In addition, mitochondrial respiration capacity is higher in high-altitude vs. lowland deer mice [96].

Exposing ectotherms to prolonged hypoxia results in a wide-range of mitochondrial responses that do not follow a general trend. For instance, mitochondrial respiration for various states and tissues is lowered in frogs [97] and eastern oysters [98], but remains unchanged in killifish liver [99] and snapper heart [100]. Respiration states of goldfish mitochondria show different responses across tissues [51]. Overall, it is impossible to predict how mitochondria respond to chronic hypoxia because some animals maintain respiration capacity while many others prefer to: (i) regulate specific respiration states that impact ATP turnover, (ii) change mitochondrial efficiency, (iii) change mitochondrial abundance, or (iv) use a combination of the above.

The known effects of chronic hypoxia on the lipid composition of the bilayer do not deal specifically with mitochondria, but with total tissue membranes [14,15]. Because mitochondrial membranes can sometimes respond to stress differently than other membranes (plasma, sarcolemma, endoplasmic reticulum), it would be interesting to investigate whether/how hypoxia affects isolated mitochondrial membranes. Diet-induced changes in membrane lipids are known to alter mitochondrial function in fish $[31,101]$ and hibernating mammals [102]. For example, rainbow trout fed a n-3 22:6-rich diet increase state 3 [101] and state 4 respiration [31]. Early studies also show that the fatty acid composition of the diet has an impact on the hibernation capacity of golden-mantled ground squirrels $[103,104]$. This interesting observation has been further explored recently in an attempt to characterize physiological links between membrane composition, mitochondrial function, hibernation capacity, and metabolic suppression. For instance, ground squirrel mitochondria suppress state 3 respiration during torpor, especially when using succinate as a substrate [105]. Changing the levels of n-6 18:2 in the diet of 13-lined ground squirrels can also markedly reduce state 3 respiration or proton leak [106], and these re- 
ductions could be used to conserve energy in hibernation [102]. The authors suggest that changes in membrane lipid composition could help to reduce the respiration capacity of mitochondria during torpor, although other mechanisms are also clearly involved [107]. Cardiolipin is a major phospholipid constituent of the inner mitochondrial membrane and plays a role in regulating complexes I [108], IV (COX) [109] and V [110]. Thus, it would be particularly useful to find out whether chronic hypoxia affects cardiolipin abundance in mitochondrial membranes. In summary, the remodeling of membrane lipids can clearly modulate mitochondrial respiration capacity and this mechanism could be used to promote metabolic suppression.

\subsection{Potential Role of Membrane Lipids in Supporting Metabolic Suppression during Chronic Hypoxia}

The membrane restructuring effects of temperature, toxins and diet discussed in Sections 2.1 and 2.2 suggest that other environmental factors like hypoxia could also influence lipid composition. Recent experimental evidence demonstrates that this is the case in two hypoxia tolerant vertebrates. We have shown that goldfish [14] and NMRs [15] undergo widespread remodeling of membrane lipids in response to prolonged in vivo exposure to low $\mathrm{O}_{2}$. Both species modulate cholesterol extensively (Figure 1), but the effects of chronic hypoxia on membrane phospholipids are more pronounced in goldfish [14] than NMRs [15] (Figure 2). Changing cholesterol abundance strongly affects the activity of membrane proteins [16-20]. Goldfish and NMR increase cholesterol in muscle and decrease it in liver, but only NMRs show a decrease in the brain. These responses are intriguing because multiple studies on artificial membranes [16,17] and manipulated fish membranes [18] show that changing cholesterol levels generally downregulates $\mathrm{Na}^{+} / \mathrm{K}^{+}$. ATPase. Therefore, this hypoxia-driven membrane response could contribute to metabolic suppression by lowering ATP demand. Another way to reduce $\mathrm{Na}^{+} / \mathrm{K}^{+}$-ATPase activity is to decrease the abundance of n-3 22:6 in membrane phospholipids because this fatty acid is an activator of the ion pump [21,22]. Lowering n-3 22:6 levels also suggests a downregulation of ATP supply from $\beta$-oxidation and the TCA cycle because n-3 PUFA are positively correlated with the maximal enzymatic activities of CPT, HOAD and CS [33,40,41,62]. Such a strategy for lowering ATP demand and supply seems to be used by the goldfish that reduces \%22:6 of liver (Figure 2) and gill membranes [14]. However, this mechanism is not available to NMRs because of their intrinsically low levels of n-3 22:6 (only 0-4\% of total membrane fatty acids in normoxic animals) that leaves little to no room for a decrease during hypoxia [15]. Overall, the hypoxia-driven changes in membrane lipids observed to date could represent a novel mechanism to reduce organismal metabolic rate in stressful environments. It is presently unclear whether this membrane response to chronic hypoxia only occurs in hypoxia tolerant species or more generally in all animals. 


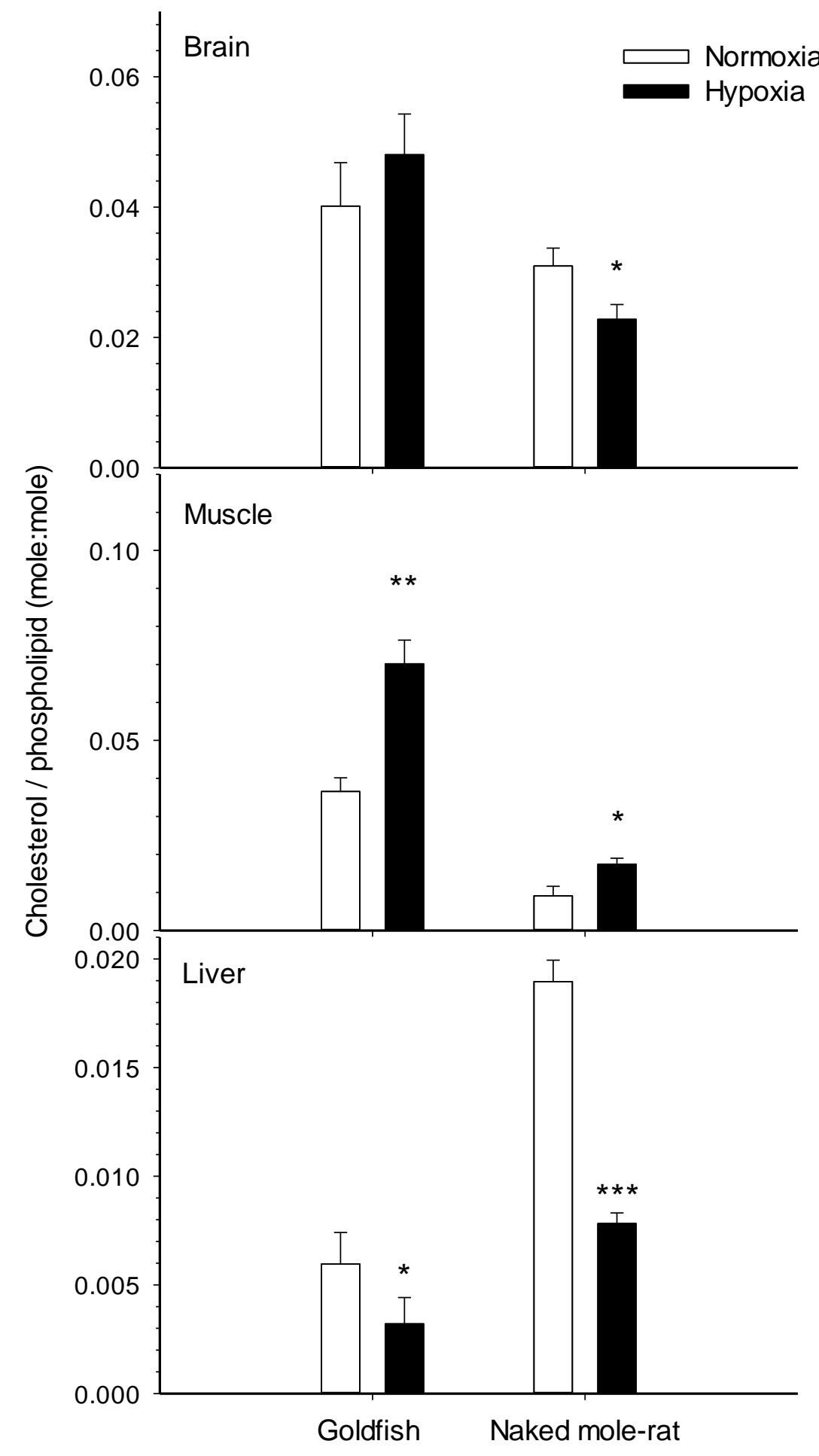

Figure 1. Relative membrane cholesterol in the tissues of normoxic controls and hypoxia-acclimated animals for two hypoxia-tolerant vertebrates: the goldfish [14] and the naked-mole rat [15]. Values are means $\pm \operatorname{SEM}\left(n=9-16\right.$ per treatment). ${ }^{*} p<0.05,{ }^{* *} p<0.01,{ }^{* * *} p<0.001$ indicate significant effects of hypoxia. 


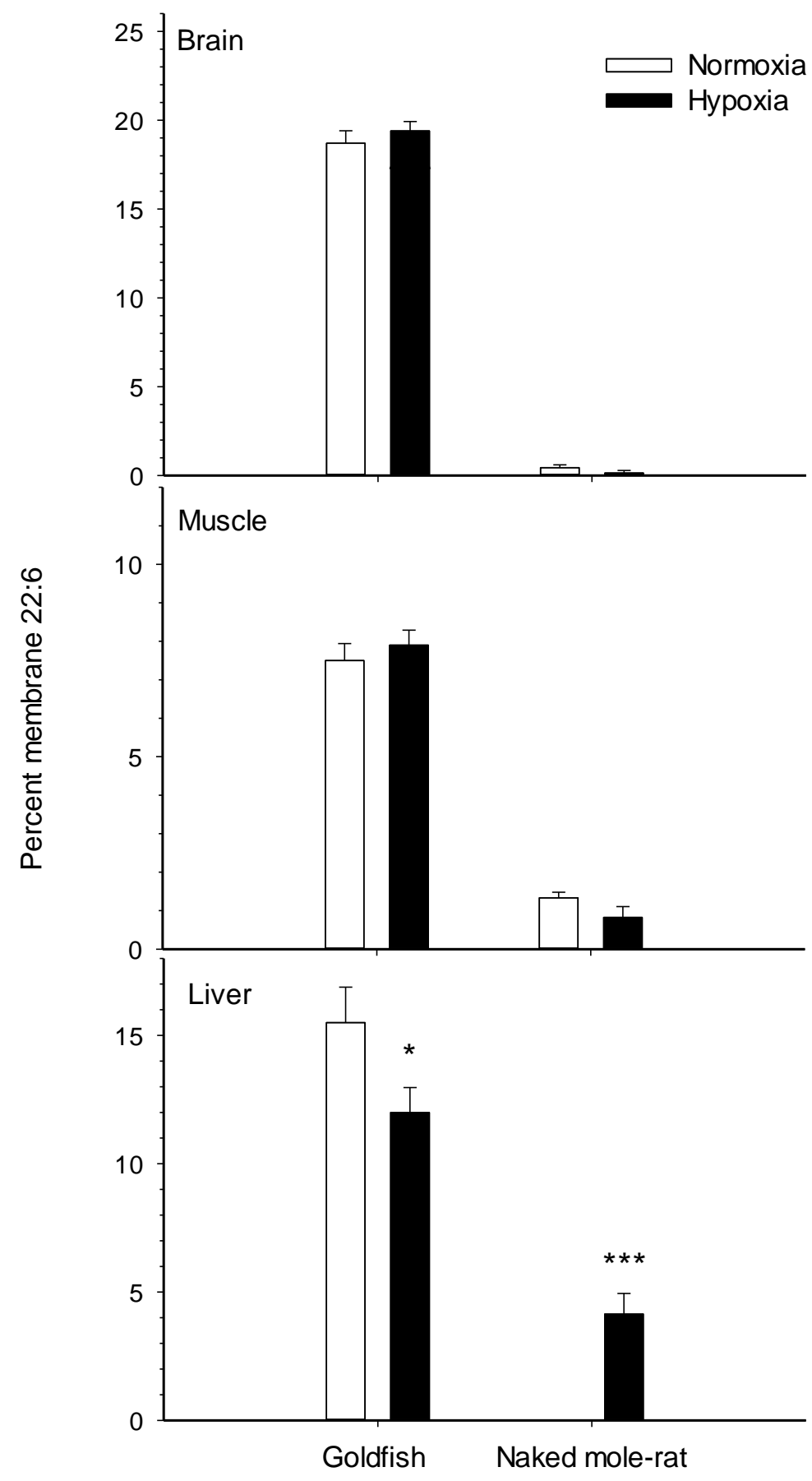

Figure 2. Percent docosahexaenoic acid (n-3 22:6) in membrane phospholipids in the tissues of normoxic controls and hypoxia-acclimated animals for two hypoxia-tolerant vertebrates: the goldfish [14] and the naked-mole rat [15]. Values are means $\pm \operatorname{SEM~}\left(n=9-14\right.$ per treatment). ${ }^{*} p<0.05$, *** $p<0.001$ indicate significant effects of hypoxia.

\section{Conclusions and Future Directions}

Current understanding of the mechanisms that cause metabolic suppression in chronic hypoxia are summarized in Figure 3. The lipid composition of membranes plays a fundamental role in setting the metabolic capacity of cells, tissues and organisms. This review has examined how animals use membrane plasticity to adjust their metabolic capacity in a wide range of physiological situations and it proposes that chronic hypoxia is among them. This versatile mechanism is maybe best exemplified by birds that boost aerobic capacity before long-distance migration (natural doping in sandpipers), scaling of mass- 
specific metabolic rate (membrane pacemaker theory of metabolism), and various studies of metabolic suppression (hibernator mitochondria and downregulation of $\mathrm{Na}^{+} / \mathrm{K}^{+}$- ATPase in artificial membranes).

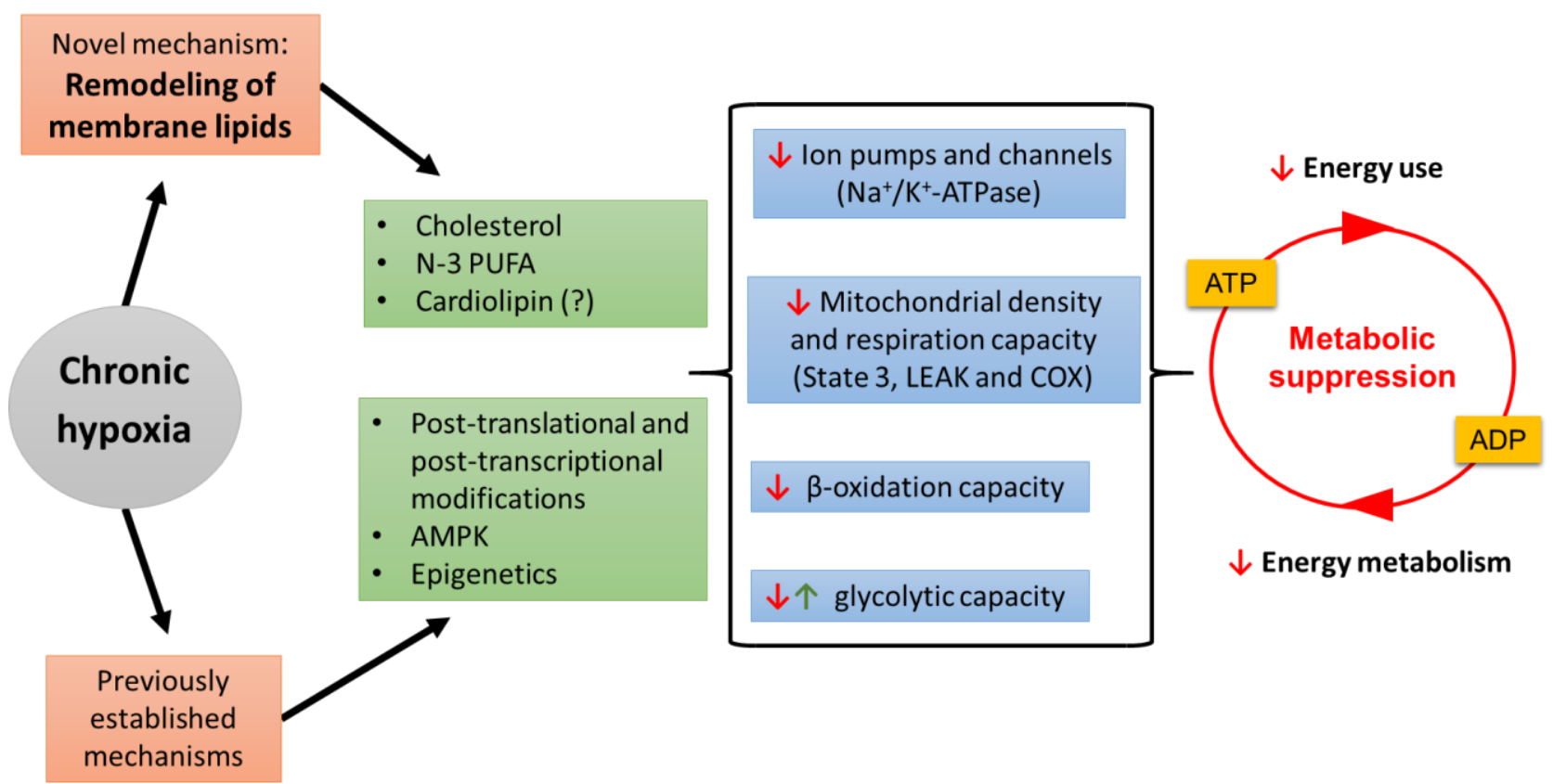

Figure 3. Remodeling of membrane lipids is a proposed new mechanism to promote metabolic suppression in chronic hypoxia. Prolonged in vivo exposure to low oxygen alters the relative abundance of membrane cholesterol, n-3 polyunsaturated fatty acids (PUFA), and possibly mitochondrial cardiolipin in ways that downregulate ion pumps such as $\mathrm{Na}^{+} / \mathrm{K}^{+}$-ATPase (a major ATP consumer), ion channels, and possibly mitochondrial respiration capacity [state 3 (OXPHOS in the presence of substrates and ADP) and LEAK (proton leak)]. Chronic hypoxia also causes a general reduction in cytochrome c oxidase (COX) indicating a decrease in mitochondrial density. The observed changes in membrane composition are known to modulate metabolic pathways of energy metabolism such as $\beta$-oxidation (downregulation) and glycolysis (up or downregulation). Reduction of flux through the ATP-ADP cycle can also be induced by previously characterized mechanisms that involve post-translational/post-transcriptional modifications [11], 5'-AMP-activated protein kinase (AMPK) [12] or epigenetic changes [13]. Membrane remodeling and established mechanisms work in concert to cause metabolic suppression.

A successful hypometabolic response relies primarily on reducing ATP use whereas lowering ATP production is easier to achieve and can be done secondarily. Therefore, mechanisms that downregulate ion pumps, ion channels and proton leak play a strategic role in setting the tolerance of organisms for hypoxia. Recent studies suggest that hypoxiainduced suppression of metabolism is partly mediated by membrane plasticity through multiple mechanisms. Organismal acclimation to low oxygen causes widespread changes in the lipid composition of membranes in two champions of hypoxia tolerance: the goldfish and the naked mole-rat (see Section 2.7). To cope with this environmental stress, these resilient animals modify their membranes in ways that support the downregulation of key enzymes directly involved in ATP turnover. In hypoxia tolerant species, entering the hypometabolic state occurs together with extensive changes in membrane cholesterol, a decrease in mitochondrial density, as well as the downregulation of brain $\mathrm{Na}^{+} / \mathrm{K}^{+}$-ATPase and acetyl-CoA supply from $\beta$-oxidation and/or glycolysis. However, a direct functional link between changes in membrane lipids and the downregulation of major ATP consuming processes remains to be further established. A common membrane signal regulating the joint inhibition of ion pumps and channels could be an exquisite way to preserve the balance between ATP supply and demand in the hypometabolic state. To investigate how membrane restructuring and metabolic suppression can be mechanistically linked, it will 
be useful to mimic the membrane changes observed in vivo on artificial membranes to characterize how ion pumps and channels are affected by hypoxia.

Hibernators seem to rely on changes in mitochondrial membrane lipids to reduce proton leak and state 3 respiration as they enter torpor, and the same mechanism could be used in hypoxia (see Section 2.6). Examining the effects of chronic hypoxia on the lipid composition of mitochondrial membranes is therefore an important avenue for future research. Do the hypoxia-driven changes already characterized for total tissue membranes echo those of mitochondrial membranes specifically? The membrane remodeling mechanisms presently linked to metabolic suppression include changes in cholesterol, fatty acid composition of phospholipids, and mitochondrial cardiolipin, but their relative importance is unknown.

While not as critical as reducing ATP use, lowering the rate of ATP synthesis is also required to keep matching ATP supply with demand in hypometabolic states. Maximal flux capacities of key metabolic pathways such as glycolysis, $\beta$-oxidation and the TCA cycle are affected by both chronic hypoxia and changes in membrane lipids. To what extent the downregulation of energy metabolism caused by hypoxia depends on membrane remodeling is currently unclear. In conclusion, we propose that membrane restructuring is a novel physiological mechanism used by animals to suppress ATP turnover during prolonged hypoxia.

Author Contributions: Conceptualization, E.F., J.-M.W.; Formal Analysis, E.F.; Investigation, E.F., J.-M.W.; Resources, J.-M.W.; Data Curation, E.F.; Writing—Original Draft Preparation, E.F.; WritingReview and Editing, E.F., J.-M.W.; Visualization, E.F.; Supervision, J.-M.W.; Project Administration, J.-M.W.; Funding Acquisition, J.-M.W. All authors have read and agreed to the published version of the manuscript.

Funding: This work was supported by the Natural Sciences and Engineering Research Council of Canada (NSERC) Discovery Grant 05955-2017 and a France Canada Research Fund (FCRF) Grant 149716-2018 (to J.-M. Weber).

Conflicts of Interest: The authors declare no conflict of interest.

\section{References}

1. Richards, J.G.; Farrell, A.P.; Brauner, C.J. Hypoxia, 1st ed.; Academic Press: London, UK, 2009; Volume 27, p. 528.

2. Lutz, P.L.; Storey, K.B. Adaptations to variations in oxygen tension by vertebrates and invertebrates. In Comprehensive Physiology; John Wiley \& Sons, Inc.: Hoboken, NJ, USA, 2010; pp. 1479-1522.

3. Diaz, R.J.; Rosenberg, R. Spreading dead zones and consequences for marine ecosystems. Science 2008, 321, 926-929. [CrossRef]

4. Stramma, L.; Johnson, G.C.; Sprintall, J.; Mohrholz, V. Expanding oxygen-minimum zones in the tropical oceans. Science 2008, 320, 655-658. [CrossRef] [PubMed]

5. Hochachka, P.W. Defense strategies against hypoxia and hypothermia. Science 1986, 231, 234-241. [CrossRef]

6. Bickler, P.E.; Buck, L.T. Hypoxia tolerance in reptiles, amphibians, and fishes: Life with variable oxygen availability. Annu. Rev. Physiol. 2007, 69, 145-170. [CrossRef]

7. Pamenter, M.E.; Lau, G.Y.; Richards, J.G.; Milsom, W.K. Naked mole rat brain mitochondria electron transport system flux and h+ leak are reduced during acute hypoxia. J. Exp. Biol. 2018, 221. [CrossRef] [PubMed]

8. Storey, K.B. Metabolic regulation in mammalian hibernation: Enzyme and protein adaptations. Comp. Biochem. Physiol. Part A Physiol. 1997, 118, 1115-1124. [CrossRef]

9. Martínez, M.L.; Landry, C.; Boehm, R.; Manning, S.; Cheek, A.O.; Rees, B.B. Effects of long-term hypoxia on enzymes of carbohydrate metabolism in the gulf killifish, fundulus grandis. J. Exp. Biol. 2006, 209, 3851-3861. [CrossRef]

10. Solaini, G.; Baracca, A.; Lenaz, G.; Sgarbi, G. Hypoxia and mitochondrial oxidative metabolism. Biochim. Biophys. Acta Bioenerg. 2010, 1797, 1171-1177. [CrossRef] [PubMed]

11. Storey, K.B.; Storey, J.M. Metabolic rate depression and biochemical adaptation in anaerobiosis, hibernation and estivation. Quart. Rev. Biol. 1990, 65, 145-174. [CrossRef]

12. Pamenter, M.E. Mitochondria: A multimodal hub of hypoxia tolerance. Can. J. Zool. 2014, 92, 569-589. [CrossRef]

13. Storey, K.B. Regulation of hypometabolism: Insights into epigenetic controls. J. Exp. Biol. 2015, 218, 150-159. [CrossRef] [PubMed]

14. Farhat, E.; Turenne, E.D.; Choi, K.; Weber, J.-M. Hypoxia-induced remodelling of goldfish membranes. Comp. Biochem. Physiol. Part B Biochem. Mol. Biol. 2019, 237, 110326. [CrossRef] [PubMed]

15. Farhat, E.; Devereaux, M.E.M.; Pamenter, M.E.; Weber, J.-M. Naked mole-rats suppress energy metabolism and modulate membrane cholesterol in chronic hypoxia. Am. J. Physiol. Regul. Integr. Comp. Physiol. 2020, 319, R148-R155. [CrossRef] 
16. Garcia, A.; Lev, B.; Hossain, K.R.; Gorman, A.; Pham, T.H.N.; Cornelius, F.; Allen, T.W.; Clarke, R.J. Cholesterol depletion inhibits na+, k+-atpase activity in a near-native membrane environment. J. Biol. Chem. 2019, 294, 5956-5969. [CrossRef]

17. Yeagle, P.L.; Young, J.; Rice, D. Effects of cholesterol on sodium-potassium atpase atp hydrolyzing activity in bovine kidney. Biochemistry 1988, 27, 6449-6452. [CrossRef]

18. Crockett, E.L.; Hazel, J.R. Cholesterol affects physical properties and (na+, k+)-atpase in basolateral membranes of renal and intestinal epithelia from thermally acclimated rainbow trout. J. Comp. Physiol. B 1997, 167, 344-351. [CrossRef]

19. Bastiaanse, E.M.L.; Höld, K.M.; Van der Laarse, A. The effect of membrane cholesterol content on ion transport processes in plasma membranes. Cardiovasc. Res. 1997, 33, 272-283. [CrossRef]

20. Harayama, T.; Riezman, H. Understanding the diversity of membrane lipid composition. Nat. Rev. Mol. Cell Biol. 2018, 19, 281. [CrossRef]

21. Calhoon, E.A.; Ro, J.; Williams, J.B. Perspectives on the membrane fatty acid unsaturation/pacemaker hypotheses of metabolism and aging. Chem. Phys. Lipids 2015, 191, 48-60. [CrossRef] [PubMed]

22. Turner, N.; Haga, K.L.; Hulbert, A.J.; Else, P.L. Relationship between body size, $\mathrm{na}^{+}-\mathrm{k}^{+}$-atpase activity, and membrane lipid composition in mammal and bird kidney. Am. J. Physiol. Regul. Integr. Comp. Physiol. 2005, 288, R301-R310. [CrossRef]

23. Hulbert, A.J.; Else, P.L. Membranes as possible pacemakers of metabolism. J. Theor. Biol. 1999, 199, 257-274. [CrossRef]

24. Hazel, J.R. Thermal adaptation in biological membranes: Is homeoviscous adaptation the explanation? Annu. Rev. Physiol. 1995, 57, 19-42. [CrossRef] [PubMed]

25. Cossins, A.; Bowler, K.; Prosser, C. Homeoviscous adaptation and its effect upon membrane-bound proteins. J. Therm. Biol. 1981, 6, 183-187. [CrossRef]

26. Anderson, R.L.; Minton, K.W.; Li, G.C.; Hahn, G.M. Temperature-induced homeoviscous adaptation of chinese hamster ovary cells. Biochim. Biophys. Acta Biomembr. 1981, 641, 334-348. [CrossRef]

27. Lewis, R.; McElhaney, R.N. The mesomorphic phase behavior of lipid bilayers. Struct. Biol. Membr. 1992, 2. [CrossRef]

28. Crockett, E.L. Cholesterol function in plasma membranes from ectotherms: Membrane-specific roles in adaptation to temperature1. Am. Zool. 1998, 38, 291-304. [CrossRef]

29. Demel, R.A.; De Kruyff, B. The function of sterols in membranes. Biochim. Biophys. Acta Rev. Biomembr. 1976, 457, 109-132. [CrossRef]

30. Gonzalez, A.; Odjélé, A.; Weber, J.-M. Pcb-153 and temperature cause restructuring of goldfish membranes: Homeoviscous response to a chemical fluidiser. Aquat. Toxicol. 2013, 144-145, 11-18. [CrossRef]

31. Martin, N.; Bureau, D.P.; Marty, Y.; Kraffe, E.; Guderley, H. Dietary lipid quality and mitochondrial membrane composition in trout: Responses of membrane enzymes and oxidative capacities. J. Comp. Physiol. B 2013, 183, 393-408. [CrossRef]

32. Nagahuedi, S.; Popesku, J.T.; Trudeau, V.L.; Weber, J.-M. Mimicking the natural doping of migrant sandpipers in sedentary quails: Effects of dietary n-3 fatty acids on muscle membranes and ppar expression. J. Exp. Biol. 2009, 212, 1106-1114. [CrossRef]

33. Pierce, B.J.; McWilliams, S.R.; O'Connor, T.P.; Place, A.R.; Guglielmo, C.G. Effect of dietary fatty acid composition on depot fat and exercise performance in a migrating songbird, the red-eyed vireo. J. Exp. Biol. 2005, 208, 1277-1285. [CrossRef]

34. Abbott, S.K.; Else, P.L.; Hulbert, A.J. Membrane fatty acid composition of rat skeletal muscle is most responsive to the balance of dietary n-3 and n-6 pufa. Br. J. Nutr. 2010, 103, 522-529. [CrossRef] [PubMed]

35. Ruf, T.; Arnold, W. Effects of polyunsaturated fatty acids on hibernation and torpor: A review and hypothesis. Am. J. Physiol Regul Integr Comp. Physiol 2008, 294, R1044-R1052. [CrossRef]

36. Weber, J.-M. The physiology of long-distance migration: Extending the limits of endurance metabolism. J. Exp. Biol. 2009, 212, 593-597. [CrossRef]

37. Frank, C.L. Short-term variations in diet fatty acid composition and torpor by ground squirrels. J. Mammal. 2002, 83, 1013-1019. [CrossRef]

38. Giroud, S.; Stalder, G.; Gerritsmann, H.; Kübber-Heiss, A.; Kwak, J.; Arnold, W.; Ruf, T. Dietary lipids affect the onset of hibernation in the garden dormouse (eliomys quercinus): Implications for cardiac function. Front. Physiol. $2018,9,1235$. [CrossRef] [PubMed]

39. Maillet, D.; Weber, J.-M. Performance-enhancing role of dietary fatty acids in a long-distance migrant: The semipalmated sandpiper. J. Exp. Biol. 2006, 209, 2686-2695. [CrossRef]

40. Maillet, D.; Weber, J.-M. Relationship between n-3 pufa content and energy metabolism in the flight muscles of a migrating shorebird: Evidence for natural doping. J. Exp. Biol. 2007, 210, 413-420. [CrossRef]

41. Hulbert, A.J.; Else, P.L. Membranes and the setting of energy demand. J. Exp. Biol 2005, 208, 1593-1599. [CrossRef] [PubMed]

42. Hulbert, A.J. Membrane fatty acids as pacemakers of animal metabolism. Lipids 2007, 42, 811-819. [CrossRef]

43. Valencak, T.G.; Ruf, T. N-3 polyunsaturated fatty acids impair lifespan but have no role for metabolism. Aging Cell 2007, 6, 15-25. [CrossRef]

44. Rodriguez, E.; Weber, J.-M.; Pagé, B.; Roubik, D.W.; Suarez, R.K.; Darveau, C.-A. Setting the pace of life: Membrane composition of flight muscle varies with metabolic rate of hovering orchid bees. Proc. R. Soc. B 2015, 282, 20142232. [CrossRef]

45. Gonzalez, A.; Pagé, B.; Weber, J.-M. Membranes as a possible pacemaker of metabolism in cypriniform fish: Does phylogeny matter? J. Exp. Biol. 2015, 218, 2563-2572. [CrossRef]

46. Rolfe, D.F.S.; Brown, G.C. Cellular energy utilization and molecular origin of standard metabolic rate in mammals. Physiol. Rev. 1997, 77, 731-758. [CrossRef] 
47. Hochachka, P.W.; Buck, L.T.; Doll, C.J.; Land, S.C. Unifying theory of hypoxia tolerance: Molecular/metabolic defense and rescue mechanisms for surviving oxygen lack. Proc. Natl. Acad. Sci. USA 1996, 93, 9493-9498. [CrossRef] [PubMed]

48. Cáceda, R.; Gamboa, J.L.; Boero, J.A.; Monge-C, C.; Arregui, A. Energetic metabolism in mouse cerebral cortex during chronic hypoxia. Neurosci. Lett. 2001, 301, 171-174. [CrossRef]

49. Benzi, G.; Gorini, A.; Arnaboldi, R.; Ghigini, B.; Villa, R. Synaptosomal non-mitochondrial atpase activities: Age-related alterations by chronic normobaric intermittent hypoxia. Neurochem. Int. 1994, 25, 61-67. [CrossRef]

50. Paajanen, V.; Vornanen, M. Effects of chronic hypoxia on inward rectifier k+ current (ik1) in ventricular myocytes of crucian carp (carassius carassius) heart. J. Membr. Biol. 2003, 194, 119-127. [CrossRef] [PubMed]

51. Farhat, E.; Cheng, H.; Romestaing, C.; Pamenter, M.; Weber, J.-M. Goldfish response to chronic hypoxia: Mitochondrial respiration, fuel preference and energy metabolism. Metabolites 2021, 11, 187. [CrossRef]

52. Turner, N.; Else, P.L.; Hulbert, A. Docosahexaenoic acid (dha) content of membranes determines molecular activity of the sodium pump: Implications for disease states and metabolism. Naturwissenschaften 2003, 90, 521-523. [CrossRef] [PubMed]

53. Wu, B.J.; Hulbert, A.J.; Storlien, L.H.; Else, P.L. Membrane lipids and sodium pumps of cattle and crocodiles: An experimental test of the membrane pacemaker theory of metabolism. Am. J. Physiol. 2004, 287, R633-R641. [CrossRef] [PubMed]

54. Else, P.; Wu, B. What role for membranes in determining the higher sodium pump molecular activity of mammals compared to ectotherms? J. Comp. Physiol. B 1999, 169, 296-302. [CrossRef] [PubMed]

55. Yeagle, P.L. Lipid regulation of cell membrane structure and function. FASEB J. 1989, 3, 1833-1842. [CrossRef] [PubMed]

56. Lau, D.S.; Connaty, A.D.; Mahalingam, S.; Wall, N.; Cheviron, Z.A.; Storz, J.F.; Scott, G.R.; McClelland, G.B. Acclimation to hypoxia increases carbohydrate use during exercise in high-altitude deer mice. Am. J. Physiol. Regul. Integr. Comp. Physiol. 2017, 312, R400-R411. [CrossRef]

57. Pastoris, O.; Dossena, M.; Foppa, P.; Arnaboldi, R.; Gorini, A.; Villa, R.; Benzi, G. Modifications by chronic intermittent hypoxia and drug treatment on skeletal muscle metabolism. Neurochem. Res. 1995, 20, 143-150. [CrossRef]

58. Daneshrad, Z.; Garcia-Riera, M.; Verdys, M.; Rossi, A. Differential responses to chronic hypoxia and dietary restriction of aerobic capacity and enzyme levels in the rat myocardium. Mol. Cell Biochem. 2000, 210, 159-166. [CrossRef]

59. Low, P.A.; Schmelzer, J.; Ward, K.; Yao, J. Experimental chronic hypoxic neuropathy: Relevance to diabetic neuropathy. Am. J. Physiol. Endocrinol. Metab. 1986, 250, E94-E99. [CrossRef]

60. Waskova-Arnostova, P.; Kasparova, D.; Elsnicova, B.; Novotny, J.; Neckar, J.; Kolar, F.; Zurmanova, J. Chronic hypoxia enhances expression and activity of mitochondrial creatine kinase and hexokinase in the rat ventricular myocardium. Cell. Physiol. Biochem. 2014, 33, 310-320. [CrossRef]

61. van den Thillart, G.; Smit, H. Carbohydrate metabolism of goldfish (Carassius auratus L.)—effects of long-term hypoxia-acclimation on enzyme patterns of red muscle, white muscle and liver. J. Comp. Physiol. B 1984, 154, 477-486. [CrossRef]

62. Johnston, I.A.; Bernard, L.M. Ultrastructure and metabolism of skeletal muscle fibres in the tench: Effects of long-term acclimation to hypoxia. Cell Tissue Res. 1982, 227, 179-199. [CrossRef]

63. Li, J.; Xu, X.; Li, W.; Zhang, X. Effects of acute and chronic hypoxia on the locomotion and enzyme of energy metabolism in chinese shrimp fenneropenaeus chinensis. Mar. Freshw. Behav. Physiol. 2018, 51, 275-291. [CrossRef]

64. Mahfouz, M.E.; Hegazi, M.M.; El-Magd, M.A.; Kasem, E.A. Metabolic and molecular responses in nile tilapia, oreochromis niloticus during short and prolonged hypoxia. Mar. Freshw. Behav. Physiol. 2015, 48, 319-340. [CrossRef]

65. Dukhande, V.V.; Sharma, G.C.; Lai, J.C.K.; Farahani, R. Chronic hypoxia-induced alterations of key enzymes of glucose oxidative metabolism in developing mouse liver are mtor dependent. Mol. Cell. Biochem. 2011, 357, 189-197. [CrossRef]

66. Pillet, M.; Dupont-Prinet, A.; Chabot, D.; Tremblay, R.; Audet, C. Effects of exposure to hypoxia on metabolic pathways in northern shrimp (pandalus borealis) and greenland halibut (reinhardtius hippoglossoides). J. Exp. Mar. Biol. Ecol. 2016, 483, 88-96. [CrossRef]

67. Zhou, B.; Wu, R.; Randall, D.; Lam, P.; Ip, Y.; Chew, S. Metabolic adjustments in the common carp during prolonged hypoxia. J. Fish. Biol. 2000, 57, 1160-1171. [CrossRef]

68. Lui, M.A.; Mahalingam, S.; Patel, P.; Connaty, A.D.; Ivy, C.M.; Cheviron, Z.A.; Storz, J.F.; McClelland, G.B.; Scott, G.R. Highaltitude ancestry and hypoxia acclimation have distinct effects on exercise capacity and muscle phenotype in deer mice. Am. J. Physiol. Regul. Integr. Comp. Physiol. 2015, 308, R779-R791. [CrossRef]

69. Nikel, K.E.; Shanishchara, N.K.; Ivy, C.M.; Dawson, N.J.; Scott, G.R. Effects of hypoxia at different life stages on locomotory muscle phenotype in deer mice native to high altitudes. Comp. Biochem. Physiol. Part. B Biochem. Mol. Biol. 2018, 224, 98-104. [CrossRef] [PubMed]

70. le Moine, C.M.R.; Morash, A.J.; McClelland, G.B. Changes in hif- $1 \alpha$ protein, pyruvate dehydrogenase phosphorylation, and activity with exercise in acute and chronic hypoxia. Am. J. Physiol. Regul. Integr. Comp. Physiol. 2011, 301, R1098-R1104. [CrossRef]

71. DiMauro, S.; Moraes, C.T. Mitochondrial encephalomyopathies. Arch. Neurol. 1993, 50, 1197-1208. [CrossRef] [PubMed]

72. Drynan, L.; Quant, P.A.; Zammit, V.A. Flux control exerted by mitochondrial outer membrane carnitine palmitoyltransferase over $\beta$-oxidation, ketogenesis and tricarboxylic acid cycle activity in hepatocytes isolated from rats in different metabolic states. Biochem. J. 1996, 317, 791-795. [CrossRef] [PubMed]

73. Galbes, O.; Goret, L.; Caillaud, C.; Mercier, J.; Obert, P.; Candau, R.; Py, G. Combined effects of hypoxia and endurance training on lipid metabolism in rat skeletal muscle. Acta Physiol. 2008, 193, 163-173. [CrossRef] 
74. Kennedy, S.L.; Stanley, W.C.; Panchal, A.R.; Mazzeo, R.S. Alterations in enzymes involved in fat metabolism after acute and chronic altitude exposure. J. Appl. Physiol. 2001, 90, 17-22. [CrossRef]

75. Dutta, A.; Vats, P.; Singh, V.K.; Sharma, Y.K.; Singh, S.N.; Singh, S.B. Impairment of mitochondrial $\beta$-oxidation in rats under cold-hypoxic environment. Int. J. Biometeorol. 2009, 53, 397. [CrossRef]

76. Morash, A.J.; Kotwica, A.O.; Murray, A.J. Tissue-specific changes in fatty acid oxidation in hypoxic heart and skeletal muscle. Am. J. Physiol. Regul. Integr. Comp. Physiol. 2013, 305, R534-R541. [CrossRef]

77. Templeman, N.M.; Beaudry, J.L.; Le Moine, C.M.R.; McClelland, G.B. Chronic hypoxia- and cold-induced changes in cardiac enzyme and gene expression in cd-1 mice. Biochim. Biophys. Acta (BBA) Gen. Subj. 2010, 1800, 1248-1255. [CrossRef]

78. Gerber, L.; Clow, K.A.; Katan, T.; Emam, M.; Leeuwis, R.H.J.; Parrish, C.C.; Gamperl, A.K. Cardiac mitochondrial function, nitric oxide sensitivity and lipid composition following hypoxia acclimation in sablefish. J. Exp. Biol. 2019, 222, jeb208074. [CrossRef]

79. Alasnier, C.; Rémignon, H.; Gandemer, G. Lipid characteristics associated with oxidative and glycolytic fibres in rabbit muscles. Meat Sci. 1996, 43, 213-224. [CrossRef]

80. Arnold, W.; Giroud, S.; Valencak, T.G.; Ruf, T. Ecophysiology of omega fatty acids: A lid for every jar. Physiology 2015, 30, 232-240. [CrossRef] [PubMed]

81. Guo, W.; Xie, W.; Lei, T.; Hamilton, J.A. Eicosapentaenoic acid, but not oleic acid, stimulates $\beta$-oxidation in adipocytes. Lipids 2005, 40, 815-821. [CrossRef] [PubMed]

82. Poveda, J.A.; Giudici, A.M.; Renart, M.L.; Molina, M.L.; Montoya, E.; Fernández-Carvajal, A.; Fernández-Ballester, G.; Encinar, J.A.; González-Ros, J.M. Lipid modulation of ion channels through specific binding sites. Biochim. Biophys. Acta (BBA) Biomembr. 2014, 1838, 1560-1567. [CrossRef] [PubMed]

83. Tillman, T.S.; Cascio, M. Effects of membrane lipids on ion channel structure and function. Cell Biochem. Biophys. 2003, 38, 161-190. [CrossRef]

84. Levitan, I.; Fang, Y.; Rosenhouse-Dantsker, A.; Romanenko, V. Cholesterol and ion channels. In Cholesterol binding and Cholesterol Transport Proteins; Springer: New York, NY, USA, 2010; pp. 509-549.

85. D'Avanzo, N. Lipid regulation of sodium channels. In Current Topics in Membranes; Elsevier: Amsterdam, The Netherlands, 2016; Volume 78, pp. 353-407.

86. Kang, J.X.; Leaf, A. Evidence that free polyunsaturated fatty acids modify na+ channels by directly binding to the channel proteins. Proc. Natl. Acad. Sci. USA 1996, 93, 3542-3546. [CrossRef]

87. Palomer, E.; Martín-Segura, A.; Baliyan, S.; Ahmed, T.; Balschun, D.; Venero, C.; Martin, M.G.; Dotti, C.G. Aging triggers a repressive chromatin state at bdnf promoters in hippocampal neurons. Cell Rep. 2016, 16, 2889-2900. [CrossRef]

88. McElroy, G.S.; Chandel, N.S. Mitochondria control acute and chronic responses to hypoxia. Exp. Cell Res. 2017, 356, 217-222. [CrossRef]

89. Schmidt-Rohr, K. Oxygen is the high-energy molecule powering complex multicellular life: Fundamental corrections to traditional bioenergetics. ACS Omega 2020, 5, 2221-2233. [CrossRef]

90. Quinlan, C.L.; Perevoschikova, I.V.; Goncalves, R.L.; Hey-Mogensen, M.; Brand, M.D. The determination and analysis of site-specific rates of mitochondrial reactive oxygen species production. In Methods in Enzymology; Elsevier: Amsterdam, The Netherlands, 2013; Volume 526, pp. 189-217.

91. St-Pierre, J.; Brand, M.D.; Boutilier, R.G. Mitochondria as atp consumers: Cellular treason in anoxia. Proc. Natl. Acad. Sci. USA 2000, 97, 8670-8674. [CrossRef]

92. Heather, L.C.; Cole, M.A.; Tan, J.-J.; Ambrose, L.J.; Pope, S.; Abd-Jamil, A.H.; Carter, E.E.; Dodd, M.S.; Yeoh, K.K.; Schofield, C.J. Metabolic adaptation to chronic hypoxia in cardiac mitochondria. Basic Res. Cardiol. 2012, 107, 268. [CrossRef] [PubMed]

93. Chávez, J.C.; Pichiule, P.; Boero, J.; Arregui, A. Reduced mitochondrial respiration in mouse cerebral cortex during chronic hypoxia. Neurosci. Lett. 1995, 193, 169-172. [CrossRef]

94. Costa, L.E.; Boveris, A.; Koch, O.R.; Taquini, A.C. Liver and heart mitochondria in rats submitted to chronic hypobaric hypoxia. Am. J. Physiol. Cell Physiol. 1988, 255, C123-C129. [CrossRef] [PubMed]

95. Dawson, N.J.; Lyons, S.A.; Henry, D.A.; Scott, G.R. Effects of chronic hypoxia on diaphragm function in deer mice native to high altitude. Acta Physiol. 2018, 223, e13030. [CrossRef] [PubMed]

96. Mahalingam, S.; McClelland, G.B.; Scott, G.R. Evolved changes in the intracellular distribution and physiology of muscle mitochondria in high-altitude native deer mice. J. Physiol. 2017, 595, 4785-4801. [CrossRef] [PubMed]

97. St-Pierre, J.; Tattersall, G.J.; Boutilier, R.G. Metabolic depression and enhanced o2 affinity of mitochondria in hypoxic hypometabolism. Am. J. Physiol. Regul. Integr. Comp. Physiol. 2000, 279, R1205-R1214. [CrossRef]

98. Sokolova, I. Mitochondrial adaptations to variable environments and their role in animals' stress tolerance. Integr. Comp. Biol. 2018, 58, 519-531. [CrossRef] [PubMed]

99. Du, S.N.; Mahalingam, S.; Borowiec, B.G.; Scott, G.R. Mitochondrial physiology and reactive oxygen species production are altered by hypoxia acclimation in killifish (fundulus heteroclitus). J. Exp. Biol. 2016, 219, 1130-1138. [CrossRef]

100. Cook, D.G.; Iftikar, F.I.; Baker, D.W.; Hickey, A.J.; Herbert, N.A. Low-o2 acclimation shifts the hypoxia avoidance behaviour of snapper (pagrus auratus) with only subtle changes in aerobic and anaerobic function. J. Exp. Biol. 2013, 216, 369-378. [CrossRef]

101. Guderley, H.; Kraffe, E.; Bureau, W.; Bureau, D.P. Dietary fatty acid composition changes mitochondrial phospholipids and oxidative capacities in rainbow trout red muscle. J. Comp. Physiol. B 2008, 178, 385-399. [CrossRef] 
102. Staples, J.F.; Brown, J.C.L. Mitochondrial metabolism in hibernation and daily torpor: A review. J. Comp. Physiol. B 2008, 178, 811-827. [CrossRef]

103. Frank, C.L.; Storey, K.B. The optimal depot fat composition for hibernation by golden-mantled ground squirrels (spermophilus lateralis). J. Comp. Physiol. B. 1995, 164, 536-542. [CrossRef]

104. Frank, C.L. The influence of dietary fatty acids on hibernation by golden-mantled ground squirrels (spermophilus lateralis). Physiol. Zool. 1992, 65, 906-920. [CrossRef]

105. Staples, J.F. Metabolic suppression in mammalian hibernation: The role of mitochondria. J. Exp. Biol. 2014, 217, 2032-2036. [CrossRef] [PubMed]

106. Gerson, A.R.; Brown, J.C.L.; Thomas, R.; Bernards, M.A.; Staples, J.F. Effects of dietary polyunsaturated fatty acids on mitochondrial metabolism in mammalian hibernation. J. Exp. Biol 2008, 211, 2689-2699. [CrossRef] [PubMed]

107. Chung, D.; Lloyd, G.P.; Thomas, R.H.; Guglielmo, C.G.; Staples, J.F. Mitochondrial respiration and succinate dehydrogenase are suppressed early during entrance into a hibernation bout, but membrane remodeling is only transient. J. Comp. Physiol. B Biochem. Syst. Environ. Physiol. 2011, 181, 699-711. [CrossRef]

108. Paradies, G.; Petrosillo, G.; Pistolese, M.; Ruggiero, F.M. Reactive oxygen species affect mitochondrial electron transport complex i activity through oxidative cardiolipin damage. Gene 2002, 286, 135-141. [CrossRef]

109. Frick, N.T.; Bystriansky, J.S.; Ip, Y.K.; Chew, S.F.; Ballantyne, J.S. Cytochrome c oxidase is regulated by modulations in protein expression and mitochondrial membrane phospholipid composition in estivating african lungfish. Am. J. Physiol. Regul. Integr. Comp. Physiol. 2010, 298, R608-R616. [CrossRef] [PubMed]

110. Kraffe, E.; Marty, Y.; Guderley, H. Changes in mitochondrial oxidative capacities during thermal acclimation of rainbow trout oncorhynchus mykiss: Roles of membrane proteins, phospholipids and their fatty acid compositions. J. Exp. Biol. 2007, 210, 149-165. [CrossRef] [PubMed] 